\title{
Developing the ICT Infrastructure for Africa: Overview of Barriers to Harnessing the Full Power of the Internet
}

\author{
Daniel Gelaw Alemneh and Samantha Kelly Hastings
}

\begin{abstract}
The synergies of numerous emerging trends are shaping creation, access, use and preservation of information resources. The digital library environment provides scholars with access to more diverse and previously unavailable contents that span myriad technologies across institutions and nations. Although the uses of Internet technologies provide new directions for scholarship, there are discrepancies among nations and regions. These technologies have not been fully exploited in Africa in particular. As research and scientific inquiry depend on both the availability of heterogeneous resources from multiple sources and their openness to easy and continued access, addressing the universal access issue is paramount. This article discusses and provides an overview of some of the barriers or principal factors most likely to influence Africa's efforts in harnessing the full power of the Internet.
\end{abstract}

\section{Introduction}

Nowadays it is difficult to identify many activities that do not use Information Communication Technologies (ICT). The Internet and related technologies have had a profound impact on the ways in which we live and work. As many of these technologies were integrated into teaching and learning activities, academic institutions and their libraries were early beneficiaries of these technological developments. ${ }^{1}$

Advancement of digital technologies is shaping creation, access, use and preservation of information resources in ways that are so profound that traditional methods and concepts of access and organization no longer are effective. Web applications, together with the growing numbers of digital library initiatives, are making resource integration much easier and providing scholars with access to more diverse and previously unavailable information sources and services. The application of ICT in education will continue to grow, and recent advances are likely to increase their range and application dramatically. ${ }^{2}$

The ever-expanding digital information resources on the Web have continued to evolve. As can be seen in Figure 1, the February 2006 Web Server 


\section{About the Authors}

Daniel Gelaw Alemneh is a doctoral candidate in Information Science, University of North Texas (dalemneh@library.unt.edu), and Samantha Kelly Hastings is an associate professor, School of Library and Information Sciences, University of North Texas (hastings@lis.admin.unt.edu). Ms. submitted 09/05; accepted 01/06; revised 02/06.

Survey received responses from more than 76 million Web sites. It is expected that 2006 will be one of the Internet's strongest years for numerical growth, possibly exceeding the record growth of 17 million hostnames in 2005. Factors in the dramatic growth include increasing use of the Internet by small businesses as Web sites and online storefronts become more affordable, strong sales of online advertising, and the explosive growth of blogs, to name a few. ${ }^{3}$

The fact that the digital world is evolving at a rapid pace without much regard for universal access issues poses new threats and problems. Various researchers have explained universality in various ways: The European Digital Libraries Research Program, for example, interprets universality in three dimensions: people (access by everyone), location (access from everywhere), and devices (access via everything including laptop, iPod, palm organizer, etc.). ${ }^{4}$ While the capacity to create digital content is great and the appetite for it seemingly insatiable, much work remains to make the infrastructure accessible to all and to increase the level of inclusiveness of digital libraries in all directions.

\section{Figure 1}

Total Sites Across All Domains August 1995-February 2006. ${ }^{5}$

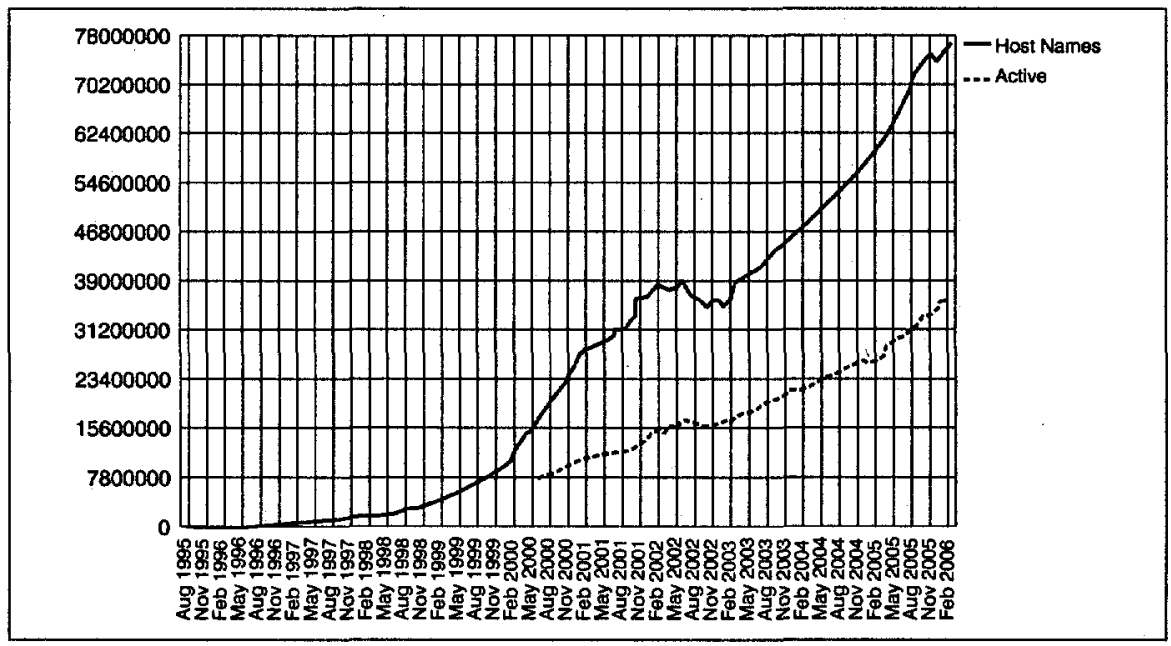




\section{Africa and Globalization}

Globalization is creating a world that is increasingly interconnected, in which the demand for global information is growing exponentially. In the current global knowledge economy, development of a national information infrastructure is part and parcel of the national development program. Power and wealth are increasingly measured by the amount of access one has to information and by one's ability to obtain and use that information effectively. ${ }^{6}$ The distinction between developed and non-developed countries has already become a distinction between countries with extensive ICT infrastructure and countries with a low level of ICT penetration, between networked nations and isolated ones. This generates both challenges and opportunities for many nations.?

Although many countries are investing heavily in the infrastructure necessary to pave and widen these routes, there are discrepancies among nations and regions. Africa is struggling to get to the information highway. There is a growing concern whether the Internet can help African countries to realize development potential or whether Internet technologies are widening the gap between the haves and have-nots. Most researchers agree that unless African countries become full actors in the global information revolution, the gap between the haves and have-nots will widen, opening the possibility to increased marginalization of the continent. ${ }^{8}$ This dramatically hampers economic development for the continent. At the moment, Africa is suffering from an absence of data for critical analysis and proper planning and forecasting regarding issues such as rural development programs and agriculture, HIV/AIDS, and malaria, tuberculosis and other infectious diseases. ${ }^{9}$ In the midst of such challenges, ICT can be used as a development tool to reduce poverty, build capacities, enrich skills, and inspire new approaches to governance and conflict resolution. Failure to bring the Internet to Africa will leave the continent farther behind than ever. $^{10}$

\section{Academic Use of Internet}

Powered by development of digital technologies and fueled by the convenience of quick and easy Web based access, research in almost every discipline is becoming more data-intensive. Digital libraries and supporting technologies have now matured to the point where their contents are incorporating complex and dynamic resources and services. In reviewing the literature of the past few years, there is no shortage of views on the role of digital libraries. Many researchers articulate a vision of a digital library environment that resonates with possibilities to create a knowledge management system on the Internet that will enable scholars to navigate through these resources in a standard, intuitive, and consistent way. "Many observers agree that the new scholarly communication systems will inevitably be based on capabilities of interoperable network technology. ${ }^{12}$ 
Considering the central role of a digital library in scholarly communication, the universal access challenge is among the fundamental concerns, and addressing this issue is a key factor to the success of digital library development at large. ${ }^{13}$

\section{African Universities}

Universities are supreme institutions of national treasure that shape competitiveness and interaction with an increasingly competitive global world. Higher institutions, especially those in Africa, are core institutions that link nations to the emerging global forces of the knowledge domain. As institutions of higher education depend more and more on digital resources, scholars will demand more and more digitally enabled resources and services. However, most African universities do not have sufficient infrastructure to utilize digital resources. The spread of the Internet in African higher education cannot be considered in isolation from the development of the Internet on the continent as a whole. ${ }^{14}$

Various reports indicate that Internet access in Africa has significantly increased (in some cases, at rates of four to five times or more) over the past five years. For example, the number of Internet users in Chad went from 1,000 to 60,000 (almost 6,000 percent use growth) and in Congo Democratic Republic by an astonishing 10,000 percent, from 500 to 50,000 during the current decade. Even with such remarkable development, the access index remains woefully low. Chad's and Congo DR's growing numbers of Internet users represented less than 1 percent penetration of the countries' populations of more than 8 and 58 million respectively. As can be seen from Table1, with $2.5 \%$ overall penetration, the Internet still remains out of reach to the vast majority of Africans. ${ }^{15}$

Furthermore, most nations still lack sufficient international bandwidth to reliably deliver various digital resources and services in any volume over the Internet. The 2004 African Tertiary Institutions Connectivity Survey (ATICS) collected information from 83 institutions, representing 40 countries in Africa, and summarized the state of Internet Connectivity by three characteristics-too little, too expensive, and poorly managed. ${ }^{16}$ The average African university has bandwidth capacity equivalent to a broadband residential connection available in the developed world and pays 50 times more for their bandwidth than their educational counterparts in the rest of the world. ${ }^{17}$ This inevitably raises the subject of telecommunications infrastructure, because Internet traffic mostly travels down ordinary telephone lines, usually those of the public telephone network. Despite some remarkable changes across the continent over the past few years, Africa teledensities remain extremely low (with around 14\% of the world's population but less than $3 \%$ of the world's telephones). Compare Sweden, with 71 telephone connections per 100 inhabitants; the USA, with 60; and Taiwan, China, with 59 ; to Chad, 0.1 ; Ethiopia 0.6 ; and Nigeria 0.8 . The pricing policy of telecommunications providers in Africa has been one of the 


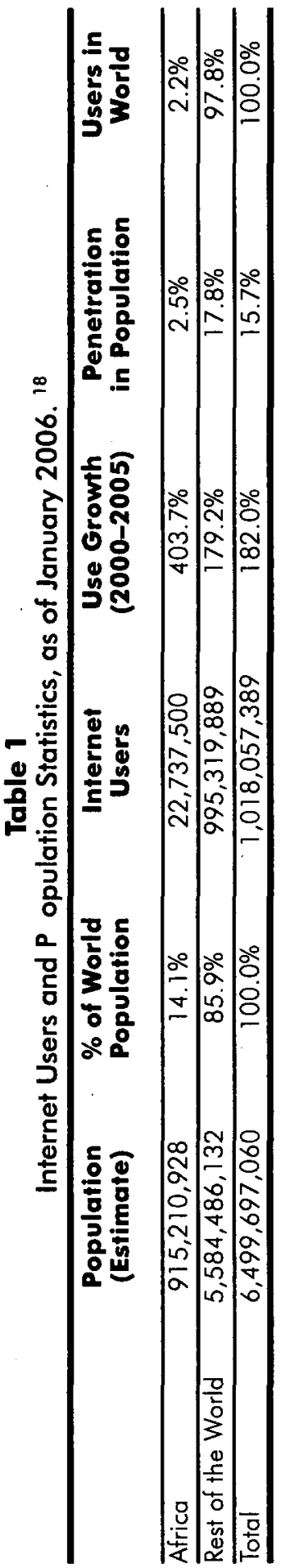


most inhibiting factors in expanding connectivity. Since telecommunications is one of the largest profit-making, state-controlled industries, most African governments fear their national telephone companies will lose revenue if they open up a competitive environment. ${ }^{19}$ This partly explains the figure in Table 1 showing less than three percent of the world's Internet traffic currently reaching Africa: the telephone network hardly exists. It also goes some way to explaining why the Internet has mushroomed in regions of the world with high telephone density: the network was already in place.

\section{Issues Related to Slow Development of Effective ICT in Teaching and Learning}

The quality of education and its out put-scientific research, technological development, and innovation-for Africa will only be valid if they are to solve real problems of Africans in the continent's fight for poverty eradication and its own development challenges. Various political and economic issues have affected institutions of higher education. A number of researchers list several reasons for this underdevelopment. ${ }^{20}$ All agree that despite the much talked-about democratization of the continent in the early $2000 \mathrm{~s}$ through efforts such as the United Nation's Millennium Development Goals (MDGs), ${ }^{21}$ the African Union's New Partnership for Africa's Development (NEPAD), ${ }^{22}$ British Prime Minister Tony Blair's Commission for Africa (that framed the basis of some of the subsequent initiatives by G-8 countries), and other bilateral agencies and partners activities, the picture has changed little for the majority of African countries. ${ }^{23}$ The saddening tale of conflict, political instability, genocide, massive population displacement, refugees and economic stagnation and/or retrogression seems endless. ${ }^{24}$

We summarize at least some of the major challenges of the African higher education institutions:

\section{Inconsistent and Restrictive Regulations and Prohibitive Policies Towards Information Exchange and Use}

With Africa having the lowest per capita income in the world, the current pricing regime of high ICT tariffs and customs duties does not actively promote connectivity. Figure 2 , from a recent Africa Tertiary Institutions Connectivity Survey (PACT 2005), shows that the average African university has bandwidth capacity equivalent to a broadband residential connection available in Europe, and Figure 2 shows that African higher institutions pays 50 times more for their bandwidth than their educational counterparts in the rest of the world. ${ }^{25}$

\section{Inadequate Budgets/Funds and Lack of Progressive National Programs for Generations}

The formulation and implementation of ICT policies has been sluggish in Africa. Many African governments remain unconvinced of the importance of research and scientific innovation in creating economic growth and they 
Figure 2

Average Bandwidth Costs/Kbps by Region-ATICS 2005. ${ }^{26}$

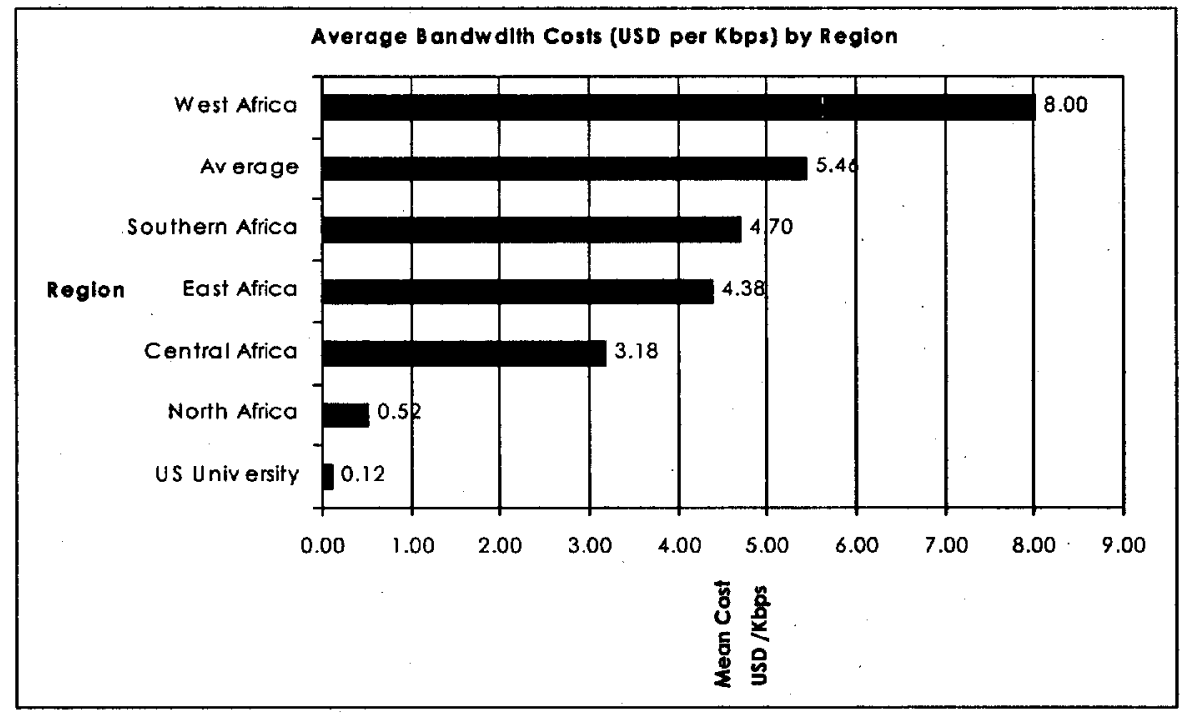

pay little attention to the national need for higher education and ICT infrastructure. Moreover, ICT policies and strategies involved lengthy processes that often diverted attention of policy makers away from the broader strategic priorities. Resources are swallowed up by pressing concerns over food security, defense, and health care. In addition, the number of students enrolled is often increasing at African universities faster than their capacity to finance this growth. There is a general agreement that educational quality is declining as a result of increased enrollments and/or reduced funding. This decline is manifested in students' low examination scores and diminished research output. Moreover, African students' involvement in the political struggle against their governments has adverse effects on the development of the universities. Universities in Ethiopia, Ghana, Kenya, Sudan, Nigeria, and other African nations were closed on a number of occasions due to political unrest. As a result of this, some governments have shown little regard for higher education and universities consequently have been inadequately funded. ${ }^{27}$

\section{Lack of Sufficient and Up-to-Date Information Sources}

The problems are compounded by the increasing number of available digital information sources. A vast mass of knowledge and data are now digitally available from various sources. A growing number of institutions are creating institutional repositories and portals to provide integrated access to their own and other open source/access resources. For example, the OpenDOAR service is being developed to support the rapidly emerging movement toward open access to research information. This will catego- 
rize and list the wide variety of open access research archives that have grown up around the world. Such repositories have mushroomed over the last two years in response to calls by scholars and researchers worldwide to provide open access to research information. Similarly, the Massachusetts Institute of Technology (MIT) offers courses online for anyone, anywhere around the world. Google's initiative to digitize some of the collections of leading research libraries is also bound to have an impact on resource sharing. Such resources can boost the quality of higher education programs and curricula, if they are actively tapped and effectively adapted and/or integrated with indigenous knowledge and resources. ${ }^{28}$

\section{Shortage of Trained ICT Professionals}

As more private businesses and public institutions are becoming computerized, the demand for competent computer experts is rapidly escalating. Although the overall level of computer literacy in Africa is low, African countries are gradually developing a small but competent base of qualified computer professionals. The quality of technical training in the continent is slowly improving and the number of professionals trained in areas of computer science and information technology is growing due to improved training opportunities. However, professionals having good ICT skills are leaving the continent or prefer not to join higher institutions and their libraries due to a combination of low salary/benefits, poor ICT infrastructure and work environments and limited opportunities. ${ }^{29}$

\section{Brain Drain}

It is difficult to retain skilled professionals at the African universities. Some treat brain drain as an extreme form of institutional displacement while others view it as a circulation of skilled labor in the emerging interdependent global economy. Whatever we call it, there is a steady flow of African immigrants to the west in pursuit of academic excellence. A large body of literature and personal observations support the view that most African scholars and students prefer to stay in the United States rather than other Western countries. The motivation of African scholars to study in the United States and stay on later results from complex pulling and pushing factors including economic, political, social, cultural, and personal matters. Many commentators agree that better job prospects, a lenient immigration policy, a less segregated socio-cultural setting, among others factors, attract African scholars to stay in the United States. The impact of each factor, however, varies from native country to native country and from individual to individual. ${ }^{30}$

All these issues have significantly prevented most African universities from developing efficient ICT-based teaching and learning environments. Internet technologies can have the potential for far-reaching impact on the future of African universities in reversing brain drain by mobilizing and tapping the large diasporic community and its rich variety of skills, exper- 
tise, resources, and status. Many members of the diaspora are products of the African institutions, and they feel strongly about contributing toward higher education development and national development in general. There are numerous ways in which this potential can be mobilized for advancing higher education in Africa. Many researchers suggest establishing intellectual networks that facilitate integration of African institutions with the knowledge centers in the major global capitals through joint research and teaching initiatives, exchange programs, and participation in academic publishing through editorial board membership and other activities. ${ }^{31}$

\section{E-Learning Developments}

Looking at the lack of a robust telecommunications infrastructure, weak regulatory frameworks, the relatively small number of Internet accounts, the few trained IT technicians, and poor maintenance services, the obstacles are obvious. Even though introducing e-learning technologies in Africa presents many challenges, the efforts aimed at overcoming them are significant and the steps from isolated projects to sustainable services can be observed all over the continent. Current e-learning collaborations in Africa include:

- The African Virtual University (AVU) was established "to build capacity and support economic development by leveraging the power of modern telecommunications technology to provide world-class quality education and training programs to students and professionals in Africa." After a successful pilot phase, AVU has been transformed from being a project of the World Bank to an independent, reputable intergovernmental organization based in Nairobi, Kenya, with more than 57 Learning Centers in 27 African countries. ${ }^{32}$

- e-Learning Africa, a conference to be held annually, intends to become the African e-learning capacity building event and a forum for all stakeholders engaged in the planning and implementation of technology-supported learning and training on the African continent. The first e-Learning Africa conference is slated for May 2006, in Addis Ababa, Ethiopia. The annual conference is supported by the United Nations Commission for Africa and the European Information Society and Media Directorate General. ${ }^{33}$

- School-Net Africa is a pan-African education portal, which provides support to practitioners, education policymakers, teachers and learners in 31 African countries. It has adopted seven major flagship programs that promote education through ICT in African schools including Building African School Net Champions, One Million Computers for African Schools, and Researching ICTs for Education in Africa. ${ }^{34}$

- European-African Pact on ICT for Development, the European Information Society Technologies (IST) initiative, with the aim to harness ICT to meet the United Nations Millennium Development Goals. Although the EU-Africa partnership for infrastructure is just at its 
start-up phase, this ambitious long-term plan marks an important milestone in Europe-Africa relations and will boost Africa's sustainable development by means of ICT. ${ }^{35}$

\section{Concluding Remarks}

Much work needs to be done on ICT reform in Africa, in order to bridge the growing digital divide. The ultimate goal of the current economic reforms in Africa should be to develop a dynamic market economy relevant to the context of Africa, in order to make Africa an integral part of the international economy. African universities need to reemerge as critical engines for economic and social development. The target of current African higher education reform should be to establish an institutional framework to fit into this new social and economic context. Developing and institutionalizing such a framework remain tremendously challenging for Africa. A series of reforms needs to be tackled, including reconciliation of the relationship between government and university, provision of academic freedom, and more autonomy to universities so they will be able to synchronize their own indigenous socioeconomic with the demands of global labor market.

African governments should wholeheartedly embrace the fact that scholars represent the center of development, self-reliance, and sustainability. This should be accomplished by the commitment of more resources and autonomy, responsibility, academic freedom, and good working facilities, not only to encourage those scholars abroad to return but also to discourage those at home from fleeing. The collaboration and cooperation among various stakeholders to harness the intellectual diaspora are vital. The importance of ICT to create and maintain active virtual scholarly communities that mobilize the intellectual diaspora cannot be overemphasized.

Creating digital opportunities through universal access will have the potential for far-reaching impact on future teaching and scholarship. African researchers will be able to participate both in the use and generation of knowledge on the Internet to provide solutions to the new demands of $21 \mathrm{st}$ century academic institutions and developing nations.

We will leave readers with a statement made by Professor Gebre Egziabher, a renowned African researcher, when he was awarded an honorary degree by Addis Ababa University:

My continent is still the most down-trodden. I would love it if every African could be so respected that she/he would be granted a visa to any country in a matter of minutes. I would like to see the queues in every European and American Embassy gate in every African capital dissolve away. ... In this age of globalization, local differences are seen as a nuisance. We are all being pushed towards congealing into an indistinguishable human mass, all of us becoming approximately American. I love globalization; but I love diversity even more. I would love the brilliance of the totality of our heterogeneity to be accessible to every point on Earth. That is the globalization for me. I recommend it for you all. I leave the unfinished business of changing globalization to be thus to you, the young. ${ }^{36}$ 


\section{References}

1. Daniel Gelaw Alemneh, The Potential Impact of the Internet on the Library and Information Services at Addis Ababa University Libraries, AAUL, Ethiopia. Unpublished M.A. thesis (University of Sheffield, UK, 1997).

2. Peter Suber, Timeline of the Open Access Movement (2006), http://www.earlham.edu/ $\sim$ peters/fos/timeline.htm (accessed February 5, 2006).

3. February 2006 Web Server Survey, http://news.netcraft.com/archives/web_server_survey.html (accessed February 5, 2006).

4. Digital Libraries: Future Directions for a European Research Program, (2005) http://www.dli2.nsf.gov/internationalprojects/eu_future.html (accessed January 26, 2006); Brian Lavoie and Lorcan Dempsey, "Thirteen Ways of Looking at . . Digital Preservation," D-Lib Magazine 10, no. 7/8 (2004), http://www.dlib.org/dlib/july04/lavoie/ 07lavoie.html (accessed January 26, 2006).

5. February 2006 Web Server Survey, http://news.netcraft.com/archives/web_server_survey.htmi (accessed February 5, 2006).

6. Robert $\mathrm{O}$. Keohane and Joseph S. Nye, Power and Interdependence in the Information Age (1998), http://www.ksg.harvard.edu/prg/nye/power.pdf (accessed February 5, 2006).

7. Daniel Gelaw Alemneh, The Potential Impact of the Internet; Damtew Tefera, "Unleashing the Forces of the Diaspora: Capitalizing on Brain Drain in the Era of Information and Communication Technologies," Diasporas Scientifiques-Scientific Diasporas, part II (CD-ROM), (2004), Chapter 6. Collection "Expertise Collegiale". Paris: IRD Editions, 226-243.

8. Damtew Teferra, Scientific Communication in African Universities: External Assistance and National Needs. New York: Routledge Falmer, 2003.

9. Lishan Adam, Bridging the Information Divide-Health and the Internet Special (2000), http:/www.balancingact-africa.com/news/back/balancing-act35.html (accessed February 5, 2006); Damtew Teferra, The World Bank Prescription for Ethiopian Higher Education: The Missing Antidote in "Pursuing the Vision" (2004), http://www2.bc. edu/\%7Eteferra/World_Bank_Study_Eth_High_Edu.html (accessed January 26, 2006).

10. Lishan Adam, Financing ICTs for Development with Focus on Poverty, (2005), http://wsispapers.choike.org/financiamiento_tic_pobreza.pdf (accessed February 5, 2006); Daniel Gelaw Alemneh, "The Role of Information Technology for Resource Sharing among Academic Libraries in Ethiopia," Proceeding of the First National Conference on Information Resource Sharing and Networking among Academic Institutions in Ethiopia, September 3-6, 1998, Addis Ababa University Libraries, Addis Ababa, Ethiopia.

11. Ron Bleed, "The IT Leader as Alchemist: Finding the True Gold," EDUCAUSE Review, 41, No.1, (Jan/Feb 2006), http://www.educause.edu/ir/library/pdf/erm0611.pdf (accessed February 5, 2006); Open Educational Resources: Free Access to Open Materials for Teaching, Learning and Research, (2006), http://topics.developmentgateway.org/ openeducation (accessed February 5, 2006).

12. Bill Birmingham, et al., EU-NSF Digital Library Working Group on Interoperability between Digital Libraries: Position Paper (2003), http://www.iei.pi.cnr.it/DELOS/ REPORTS/interop.htm (accessed January 26, 2006).

13. Anne Buck, Richard Flagan and Betsy Coles, Scholars' Forum: A New Model For Scholarly Communication (1999), http://library.caltech.edu/publications/scholarsforum/ (accessed January 26, 2006); Douglas Tudhope and Traugott Koch, eds., "New Applications of Knowledge Organization Systems: Introduction to a Special Issue," Journal of Digital Information, 4, no. 4 (2004) http://jodi.ecs.soton.ac.uk/Articles/v04/i04/editorial/ (accesses September 14, 2005).

14. Damtew Teferra, "Knowledge Creation and Dissemination in African Universities with Special Reference to Information and Communication Technologies (ICT)," in P.T. 
Zelezaand A. Olukoshi, eds., African Universities in the 21st Century. Dakar, Senegal: Council for the Development of Social Science Research in Africa, (2004), 376-399; Dawit Bekele, "Computer Standards in Ethiopia," PC Ethiopia 1, no. 2 (1999), http://ecosa.ethiopiaonline.net/docs/articles/PCEthiopia.v1n2.htm (accessed January 26, 2006).

15. ICT Indicators. International Telecommunication Union (ITU), (2006), http://www.itu.int/ITU-D/ict/statistics/ (accessed February 5, 2006); Internet Usage Statistics for Africa, (2006), http://www.internetworldstats.com/stats1.htm (accessed February 5,2006 ).

16. Roy Steiner, et al., Connectivity in African Tertiary Institutions-The ATICS Survey (2005), http://www.atics.info/ATICS2004Report.pdf (accessed February 4, 2006).

17. Optimizing Internet Bandwidth in Developing Country Higher Education, International Network for the Availability of Scientific Publications (INASP) Report (2003), http://www.inasp.info/pubs/bandwidth/; Study on the Use and Application of Information and Communication Technologies in Higher Education Institutions in Africa (2001), http://www.aau.org/english/documents/lCT-GUID.pdf (accessed February 5, 2006).

18. Internet World Stats: Usage and Population Statistics, (2006), http://www. internetworldstats.com/stats 1.htm (accessed February 5, 2006).

19. Lishan Adam, National ICT Policies Making in Africa: Implications for CSOs (2005), http://www.ssrc.org/programs/itic/publications/knowledge_report/memos/ adammemo4.pdf (accessed February 5, 2006); ICT Indicators. International Telecommunication Union (ITU); Thomas J. Afullo, "Global Information and Africa: The Telecommunications Infrastructure for Cyberspace," Library Management 21, no.4 (2000): 205-214, http:/www.emeraldinsight.com/Insight/ViewContentServlet?Filename=Published/EmeraldFullTextArticle/Articles/0150210406.html (accessed February 5, 2006).

20. "Report of the Conference on African Research and Education Network Infrastructure," (Tunis, November 14 and 15, 2005), http://www.aau.org/tunis/presentation/proceedings. pdf (accessed January 26, 2006).

21. The UN Millennium Development Goals, http://www.un.org/millenniumgoals/ (accessed February 5, 2006).

22. The New Partnership for Africa's Development (NEPAD), http://www.nepad.org/ (accessed February 5, 2006).

23. The Commission for Africa, http://www.commissionforafrica.org/ (accessed February 5, 2006); "Speech delivered by the British Prime Minister Tony Blair at the meeting of the Commission of Africa" (Addis Ababa, October 7, 2004), http://www.waltainfo.com/Conflict/BasicFacts/2004/Oct/state_02.htm (accessed February 5, 2006).

24. Africa: A Continent for the Third Millennium (2001), http://bmj.bmjjournals.com/cgi/content/full/322/7277/0 (accessed January 26, 2006); Barbara Schoetzau, "Six US Foundations Give $\$ 200$ Million to African Higher Education", VOA News. (September 16, 2005), http://www.voanews.com/english/2005-09-16-voa76.cfm (accessed January 26, 2006).

25. Promoting African Research and Education Networking (PAREN). A Study Sponsored by IDRC. (2005) http:/www.idrc.ca/uploads/user-S/1 1083295861PAREN_Reportv15.doc (accessed February 6, 2006).

26. Roy Steiner, et al., Connectivity in African Tertiary Institutions-The ATICS Survey.

27. Lishan Adam, National ICT Policies Making in Africa; Daniel Gelaw Alemneh, The Potential Impact of the Internet.

28. DOAR, http://www.opendoar.org; MIT's Open Course Ware, http://ocw.mit.edu/index.html; Open Source Initiatives (OSI) http://opensource.usrbinmby.net/index.php; Jeffrey R. Young, "Google Answers Complaints About Project to Scan Millions of Books, but Publishers Are Not Won Over," The Chronicle of Higher Education, (August 12, 2005), http://chronicle.com/free/2005/08/2005081201 t.htm (all accessed February 5, 2006). 
29. "Educating Africa, Virtually," News, (Nov 17, 2005), http://www.insidehighered. $\mathrm{com} /$ news/2005/11/17/africa (accessed February 5, 2006); Study on the Use and Application of Information and Communication Technologies in Higher Education Institutions in Africa.

30. Damtew Teferra, "Mobilizing the African Diaspora," International Higher Education, 35 , (Spring 2004), http://www.bc.edu/bc_org/avp/soe/cihe/newsletter/News35/text012.htm (accessed January 26, 2006).

31. Ainalem Tebeje, "Brain Drain and Capacity Building in Africa" (2005) http://www.idrc. ca/en/ev-71249-201-1-DO_TOPIC.html (accessed February 5, 2006).

32. The African Virtual University (AVU) http://www.avu.org/ (accessed February 5, 2006). The quotation is from the "about us" page.

33. E-Learning Africa http://www.elearning-africa.com/ (accessed February 5, 2006).

34. School Net Africa http://www.schoolnetafrica.net/ (accessed February 5, 2006).

35. EU-Africa Partnership for Infrastructure, http://europa-eu-un.org/articles/en/article_5453_en.htm (accessed February 5, 2006); European Commission adopts "European Union Strategy for Africa", (2005), http://europa.eu.int/rapid/pressReleasesAction. do?reference $=I P / 05 / 1260 \&$ format $=H T M L \&$ aged $=0 \&$ language $=E N \&$ guiLanguage $=e n$ (accessed February 6, 2006).

36. Tewolde Berhan Gebre Egziabher, "A Speech Delivered by One of the Five Recipients of Honorary Doctorate Degrees from Addis Ababa University at the Occasion of the Graduation Ceremony," (July 24, 2004), http://www2.bc.edu/\%7Eteferra/Honorary\%20Doctorate-Tewolde-Berhan-GE-Speech.html (accessed January 26, 2006). 